\title{
Diversity of butterfly communities in different habitats in limestone tropical rain forest of Vietnam
}

\author{
Разнообразие сообществ Аневных чешуекрылых разАичных \\ местообитаний произрастаюшего на карбонатных почвах \\ дождевого тропического меса Вьетнама
}

\author{
Vu Van Lien \\ Ву Ван $\Lambda$ ьен
}

Vietnam National Museum of Nature, VAST, 18 Hoang Quoc Viet, Cau Giay, Hanoi, Vietnam. E-mail: vulien@vnmn.vast.vn
Национальный Музей Природы Вьетнама, VAST, 18 Хоанг Куок Вьет, Кау Гай, Ханой, Вьетнам.

KEY WORDS: Butterflies, conservation, distribution range, secondary forest, species, individuals, Vietnam.

КЛЮЧЕВЫЕ СЛОВА: Дневные чешуекрылые, сохранение, распространение, вторичный лес, виды, особи, Вьетнам.

ABSTRACT. Diversity of butterfly communities of a limestone tropical rain forest was carried out in four different habitat types (the natural forest, the secondary forest, the shrub and grass, and the inhabitant) in Xuan Son National Park, North Vietnam from 2010 to 2012. A total 139 species with 1,041 individuals of butterflies were recorded. The secondary forest has the greatest individual and species numbers; the shrub and grass habitat has more individual and species numbers than the natural forest; the inhabitant has the least individual and species numbers. The species composition and abundance of butterfly communities is similar between similar habitats (the natural forest and the secondary forest; and the shrub and grass and the inhabitant). There was a positive correlation between the size of species geographical distribution and the increasing forest habitat clearance levels. Although the natural forest has lower butterfly diversity, it is home of restrict geographical distribution range where plays an important role for conservation of rare butterfly species; the secondary forest plays an important role in conserving higher butterfly diversity; while the inhabitant shows the poorest butterfly diversity.

РЕЗЮМЕ. С 2010 по 2012 гг. в четырёх местообитаниях (естественный лес, вторичный лес, заросли кустарника и трав, антропогенный ландшафт на границе леса) национального парка Хуан Сон (северный Вьетнам) изучали разнообразие сообществ дневных чешуекрылых дождевого тропического леса, произрастающего на карбонатных почвах. За время исследований зарегистрирована 1041 особь, относящаяся к 139 видам. Наибольшим численным обилием и видовым разнообразием отличался вторичный лес; общая численность и количество видов в кустарниково-травянистом биотопе оказалась выше, чем в естественном лесу; наимень- шим численным и видовым обилием характеризовался антропогенный ландшафт. Наибольшее сходство видового состава и численного обилия наблюдается между сообществами, формирующимися в сходных по условиям местообитаниях (естественный и вторичный леса, кустарниково-травянистый и антропогенный биотопы). Установлено, что в свободных от леса биотопах достоверно возрастает число широко распространённых видов. Несмотря на низкое видовое разнообразие, естественный лес ограничивает распространение отдельных видов, а также играет важную роль в сохранении редких видов дневных чешуекрылых. Наибольший вклад в поддержание высокого видового разнообразия вносит вторичный лес, тогда как в антропогенном ландшафте этот показатель минимален.

\section{Introduction}

Insect diversity is usually highest in habitats with the most plant diversity and is lowest in agriculture land and open areas [DeVries, 1992; Vu, 2009, 2013]. The diversity of beetle and some moth groups is high in natural forests and low in secondary forests [Morse et al., 1988; Barlow, Woiwod, 1989]. Butterfly diversity however, is usually lower in natural forests, higher in disturbed forests or secondary forest [Blair, Launer, 1997; Bobo et al., 2006; Brown, 1996; Fermon et al., 2005; Schulze et al., 2004] and highest in the forest edges [ $\mathrm{Vu}, 2009]$. Other studies have also indicated that the numbers of butterfly species and individuals are high in disturbed and regenerating forests and low in natural forests [Spitzer et al, 1993; Vu, Yuan, 2003]. Warren [1985] indicated that there were few butterfly species in the habitat with thick forest canopy and vice verse more butterfly species in the habitat with less forest canopy. Diversity of butterflies 
increases with increasing of habitat scale and vegetation structure complex [Price, 1975]. This shows that a forest habitat with more forest canopy layers and high vegetation diversity supports more insect species than a forest habitat with less forest canopy layers and less vegetation diversity. Butterfly diversity is also high in stream sides in the forest [ $\mathrm{Vu}, 2011 ; \mathrm{Vu}, \mathrm{Vu}, 2011$ ].

The diversity of butterfly communities has been studied in different habitat types of tropical rain forests in different parts of the world including tropical forest of Vietnam [Vu, 2011]. However, there have not been many studies on the diversity of butterfly communities in environments of limestone tropical forests. Limestone tropical rain forest is a special forest may play an important role in conserving a portion of tropical biodiversity, of which insects are a major part but a little data is available in these forests. The paper presents how the diversity of butterfly communities at different habitat types of limestone tropical rain forest of Vietnam.

\section{Materials and methods}

\section{Research study}

Research was carried out in Xuan Son National Park. Xuan Son was recognized as a protected area in 1986, a nature reserve in 1992, and a national park in 2002. The park is located in Phu Tho province, North Vietnam $\left(21^{\circ} 03^{\prime}-21^{\circ} 12^{\prime}\right.$ North and $104^{\circ} 51^{\prime}-105^{\circ} 01^{\prime}$ East). The Park has 18,369 ha. The core area of the park is $15,048 \mathrm{ha}$; of which the restricted protected area is 11,148 ha. It consists of 2,432 ha of primary forest on limestone forest with many caves and streams in the area. The average altitude of the park is $800 \mathrm{~m}$ a.s.l. The highest peak is $1,300 \mathrm{~m}$ a.s.l.

The average temperature in the area is from 22 to 23 Degree Celsius. There are 4 seasons: winter season from November to March next year with average temperature below 20 Degree Celcius. The coldest month average temperature is in January. The summer is from May to August. The hottest months are June and July (average of 28 Degree Celsius)

The study was conducted out at four $600-\mathrm{m}$ transects at different habitats. Transects are along the forest paths and local roads, as following:

The natural forest: in Xom Du village with altitude of 600 to $700 \mathrm{~m}$ a.s.l. The forest is almost natural forest; some disturbance of forest as a few big trees cut down in the past. The forest canopy is up to about $30 \mathrm{~m}$ a.s.l. The trees are big with diameter about $30-50 \mathrm{~cm}$. The forest canopy cover is $70 \%$.

The secondary forest: in Xom Du village with altitude of 400-450 $\mathrm{m}$ a.s.l. The transect is along the forest path. The trees are medium to small with diameter about $10-30 \mathrm{~cm}$. The forest canopy cover is $50 \%$.

The shrub and grass: along the local road in Xom Du village, altitude of $400-450 \mathrm{~m}$ a.s.l. The vegetation is shrub and small trees, and different kinds of grasses.

The inhabitant: in Xom Du village with altitude of $400 \mathrm{~m}$ a.s.l. There are agricultural plants such as rice, sweet potatoes, bananas, oranges and limes, and vegetables such as cabbages. Local wood houses of minority of Dao people with gardens and some pools are in the area.

The study was carried out for 7 days in June 2010, 6 days in May 2011, and 7 days in June 2012.

\section{Sampling methods}

A modification of the line transect count [Pollard, 1977] was used to determine species richness and abundance of butterfly communities in different habitats. The transect method were used in Vietnam in previous works [Spitzer et al., 1997; Vu, Yuan, 2003; Vu, 2009]. The method may pose some problems for assessing species richness and relative abundance of butterflies in tropical rain forests; however, this is a suitable method for surveying butterflies in a wide range of habitats including tropical rain forests [Caldas, Robbins, 2003; Posa, Sodhi, 2006; Vu, 2009].

Transect surveys took place between 8:30 am and 4:30 pm on fine days. It took about 50 minutes for each transect. Transects were counted one to twice daily. The sample times for each transect were alternated from day to day, to reduce the effect of different recording times on the data recorded. The surveyors walked at a uniform pace and recorded all butterflies.

\section{Data analysis}

Indices of diversity, evenness, and species richness of butterfly communities were assessed for each habitat type, and calculated using Primer v5 software [PrimerE Ltd, 2001] running in Window 8. The similarity of species composition between habitat types (Bray-Curtis similarity with square root transformation) was analyzed with Cluster Analysis using Similarity Tree software.

Identification and nomenclature of butterfly species were followed Chou [1994], D’Abrera [1982-1985], Monastyrskii and Devyatkin [2003]. The family system in the work was used old system as the Families Danaidae, Satyridae, Amathusiidae, and Nymphalidae are separated to analyze.

Information on the geographical distribution of each species was taken from Chou [1994], D’Abrera [19821985], Hill \& Monastyrskii [1999], Lekagul et al. [1977], Spitzer et al. [1993, 1997], Vu [2009, 2013]. The geographical distribution ranges $(\mathrm{R})$ of species were categorized on a scale from 1 to 5 (smallest to largest): R1 Endemic: East Himalayas, South China, North Indochina; R2 - Southeast Asian mainland; R3 - IndoMalayan region; R4 - Indo-Malayan and Australasian regions; and Palaearctic, extending into the Indo-Malayan region; R5 - Old World tropics, Holarctic, or Cosmopolitan.

\section{Results}

A total 139 different species with 1,041 individuals of butterflies were recorded in four different habitat types in the studied period in 2010 to 2012 . The butterfly list and their abundance are presented in Table 1. A species listed 
Table 1. Species list, distribution range and abundance of butterflies in different habitats. Таблица 1. Список видов и численное обилие дневных чешуекрылых в различных местообитаниях, с указанием их географического распространения.

\begin{tabular}{|c|c|c|c|c|c|c|}
\hline \multirow{2}{*}{ No } & \multirow{2}{*}{ Family, species } & \multirow{2}{*}{ DR } & \multicolumn{4}{|c|}{ Habitats } \\
\hline & & & NF & SF & $\mathrm{SH}$ & $\mathrm{IH}$ \\
\hline \multicolumn{7}{|c|}{ Papilionidae } \\
\hline 1 & Atrophaneura varuna (White, 1868) & 2 & 2 & & & \\
\hline 2 & Graphium agamemnon (Linnaeus, 1758) & 4 & & 2 & 3 & \\
\hline 3 & Graphium doson (C. Felder et R. Felder, 1864) & 3 & 1 & 6 & 3 & 2 \\
\hline 4 & Graphium sarpedon (Linnaeus, 1758) & 4 & & 7 & 5 & 4 \\
\hline 5 & Lamproptera curius (Fabricius, 1787) & 3 & & 15 & 10 & 6 \\
\hline 6 & Lamprotera meges (Zinken-Sommet, 1831) & 3 & 2 & 9 & 4 & \\
\hline 7 & Papilio paris Linnaeus, 1758 & 3 & & 4 & 2 & 1 \\
\hline 8 & Papilio bianor (Cramer, 1777) & 4 & 2 & 4 & 1 & \\
\hline 9 & Papilio demoleus Linnaeus, 1758 & 4 & & & 3 & 4 \\
\hline 10 & Papilio dialis doddsi Janet, 1896 & 1 & 2 & 1 & & \\
\hline 11 & Papilio helenus (Linnaeus, 1758) & 4 & 2 & 5 & 2 & 1 \\
\hline 12 & Papilio memnon Linnaeus, 1758 & 3 & 2 & 7 & 3 & 1 \\
\hline 13 & Papilio nephelus (Boisduval, 1836) & 3 & 1 & 3 & 2 & \\
\hline 14 & Papilio polytes (Linnaeus, 1758) & 3 & & 4 & 3 & 4 \\
\hline 15 & Papilio protenor Cramer, 1775 & 2 & 4 & 9 & 4 & \\
\hline 16 & Troides aeacus (C. Felder et R. Felder, 1860) & 3 & 2 & & & \\
\hline \multicolumn{7}{|c|}{ Pieridae } \\
\hline 17 & Appias albina (Boisduval, 1836) & 4 & 2 & 8 & 5 & 2 \\
\hline 18 & Appias lyncida (Cramer, 1777) & 3 & & 4 & 5 & \\
\hline 19 & Appias nero (Fabricius, 1793) & 3 & & 2 & 2 & 1 \\
\hline 20 & Catopsilia pomona (Fabricius, 1775) & 5 & & 5 & 15 & 8 \\
\hline 21 & Cepora nadina (Lucas, 1852) & 3 & & 5 & 2 & 1 \\
\hline 22 & Cepora nerissa (Fabricius, 1775) & 3 & 1 & 4 & 2 & \\
\hline 23 & Delias pasithoe (Linnaeus, 1767) & 3 & & 5 & 2 & 1 \\
\hline 24 & Dercas verhuelli (van de Hoeven, 1839) & 2 & 1 & 4 & 2 & \\
\hline 25 & Eurema andersonii (Moore, 1886) & 3 & & 4 & 3 & \\
\hline 26 & Eurema blanda (Boisduval, 1836) & 4 & & & 6 & 7 \\
\hline 27 & Eurema hecabe (Linnaeus, 1758) & 4 & & 3 & 3 & 5 \\
\hline 28 & Hebomoia glaucippe (Linnaeus, 1758) & 3 & 1 & 2 & 3 & 1 \\
\hline 29 & Ixias pyrene (Linnaeus, 1764) & 3 & 1 & 2 & 1 & \\
\hline 30 & Pieris canidia (Linnaeus, 1768) & 4 & & & 10 & 18 \\
\hline 31 & Prioneris thestylis (Doubleday, 1842) & 3 & 2 & 6 & 3 & \\
\hline \multicolumn{7}{|c|}{ Danaidae } \\
\hline 32 & Danaus genutia (Cramer, 1779) & 4 & & & 3 & 1 \\
\hline 33 & Euploea core (Cramer, 1780) & 3 & 2 & 4 & 1 & \\
\hline
\end{tabular}


Table 1. Continue Таблица 1. Продолжение

\begin{tabular}{|c|c|c|c|c|c|c|}
\hline 34 & Euploea eunice (Godart, 1819) & 3 & 1 & 3 & & \\
\hline 35 & Euploea mulciber (Cramer, 1777) & 3 & 2 & 12 & 7 & 4 \\
\hline 36 & Euploea tulliolus (Fabricius, 1793) & 4 & & 2 & 2 & \\
\hline 37 & Ideopsis similis (Linnaeus, 1758) & 3 & 2 & 1 & 3 & \\
\hline 38 & Parantica aglea (Stoll, 1782) & 4 & 2 & 5 & & \\
\hline 39 & Parantica melaneus (Cramer, 1775) & 3 & 2 & 4 & 1 & \\
\hline 40 & Parantica sita (Kollar, 1844) & 3 & 2 & 3 & & \\
\hline 41 & Tirumala limniace (Cramer, 1775) & 3 & & 2 & 1 & \\
\hline 42 & Tirumala septentrionis (Butler, 1874) & 4 & 3 & 8 & 4 & 1 \\
\hline \multicolumn{7}{|c|}{ Satyridae } \\
\hline 43 & Ethope noirei (Janet, 1896) & 1 & 3 & & & \\
\hline 44 & Lethe confusa Aurivillius, 1897 & 3 & 1 & 2 & 2 & 3 \\
\hline 45 & Lethe kansa (Moore, 1857) & 2 & 2 & 1 & & \\
\hline 46 & Lethe chandica (Moore, 1858) & 3 & 3 & 1 & & \\
\hline 47 & Lethe verma $($ Kollar, 1844) & 3 & 2 & 1 & 1 & \\
\hline 48 & Lethe vyndhia (C. Felder et R. Felder, 1859) & 2 & 1 & 1 & & \\
\hline 49 & Melanitis leda (Linnaeus, 1758) & 5 & 3 & 4 & 2 & 3 \\
\hline 50 & Melanitis phedima (Cramer, 1780) & 3 & 2 & 2 & 1 & \\
\hline 51 & Mycalesis inopia Fruhstorfer, 1908 & 1 & 5 & 2 & & \\
\hline 52 & Mycalesis misenus de Nicéville, 1901 & 1 & 7 & 5 & 1 & \\
\hline 53 & Ragadia crisilda Hewitson, 1862 & 2 & 12 & 5 & & \\
\hline 54 & Ypthima baldus (Fabricius, 1775) & 3 & & 4 & 3 & 6 \\
\hline 55 & Ypthima imitans Elwes \& Edwards, 1893 & 1 & 2 & 3 & & \\
\hline 56 & Ypthima watsoni (Moore, 1893) & 2 & 1 & 2 & 2 & \\
\hline
\end{tabular}

\section{Amathusiidae}

\begin{tabular}{l|l|l|l|l|l|l}
57 & Discophora sondaica Boisduval, 1836 & 3 & 1 & 3 & 1 & \\
\hline 58 & Faunis canens (Hübner, 1826) & 2 & 2 & 2 & & \\
\hline 59 & Faunis eumeus (Drury, 1773) & 2 & 3 & 2 & & \\
\hline 60 & Stichophthalma fruhstorferi Röber, 1903 & 1 & 1 & & & \\
\hline 61 & Stichophthalma howqua (Westwood, 1851) & 1 & 7 & 3 & & \\
\hline
\end{tabular}

Nymphalidae

\begin{tabular}{l|l|l|l|l|l|l}
\hline 62 & Argyreus hyperbius (Linnaeus, 1763) & 3 & & & 4 & 2 \\
\hline 63 & Athyma asura Moore, 1858 & 2 & 1 & 2 & 1 & \\
\hline 64 & Athyma cama Moore, 1858 & 2 & & & 2 & \\
\hline 65 & Athyma perius (Linnaeus, 1785$)$ & 3 & 1 & 2 & & \\
\hline 66 & Athyma nefte (Cramer, 1780) & 2 & 1 & 2 & 1 & \\
\hline 67 & Athyma selenophora (Kollar, 1844) & 3 & 1 & 3 & 2 & \\
\hline 68 & Athyma ranga Moore, 1857 & 2 & 1 & 4 & 2 & \\
\hline 69 & Athyma zeroca Moore, 18725 & 2 & & & 2 & \\
\hline
\end{tabular}


Table 1. Continue Таблица 1. Продолжение

\begin{tabular}{|c|c|c|c|c|c|c|}
\hline 70 & Cethosia biblis (Drury, 1773) & 3 & & & 6 & 2 \\
\hline 71 & Cethosia cyane (Drury, 1773) & 2 & & 2 & 1 & \\
\hline 72 & Charaxes aristogiton C.Felder, 1867 & 2 & 2 & 1 & & \\
\hline 73 & Chersonesia risa (Doubleday, 1848) & 3 & 15 & 6 & & \\
\hline 74 & Cirrochroa tyche C. Felder \& R. Felder, 1861 & 3 & & 6 & 3 & 2 \\
\hline 75 & Cupha erymanthis (Drury, 1773) & 3 & 2 & 2 & 1 & \\
\hline 76 & Cyrestis cocles (Fabricius, 1787) & 3 & 1 & 1 & & \\
\hline 77 & Cyrestis thyodamas Boisduval, 1836 & 3 & & & 2 & 1 \\
\hline 78 & Euthalia lubentina (Cramer, 1777) & 3 & 1 & 2 & 1 & \\
\hline 79 & Euthalia monina (Moore, 1859) & 3 & 2 & 1 & & \\
\hline 80 & Euthalia teuta (Doubleday, 1848) & 3 & 3 & 1 & & \\
\hline 81 & Hestina nama (Doubleday, 1844) & 3 & & & 2 & \\
\hline 82 & Hypolimnas bolina (Linnaeus, 1758) & 4 & 1 & 2 & 1 & 3 \\
\hline 83 & Junonia almana (Linnaeus, 1758) & 3 & & 2 & 7 & 8 \\
\hline 84 & Junonia iphita (Cramer, 1779) & 3 & & & 3 & 5 \\
\hline 85 & Junonia orythia (Linnaeus, 1758) & 4 & & & 1 & 1 \\
\hline 86 & Kallima inachus (Boisduval, 1846) & 2 & 2 & 2 & & \\
\hline 87 & Kanisca canace (Linnaeus, 1763) & 3 & 2 & 3 & & \\
\hline 88 & Lebadea martha (Fabricius, 1787) & 3 & 1 & 1 & & \\
\hline 89 & Lexias pardalis Moore, 1878 & 3 & 2 & 2 & & \\
\hline 90 & Neptis clinia (Moore, 1872) & 3 & & 4 & 8 & \\
\hline 91 & Neptis harita Moore, 1875 & 3 & 1 & 2 & & \\
\hline 92 & Neptis hylas (Linnaeus, 1758) & 4 & & & 2 & 2 \\
\hline 93 & Neptis sappho (Pallas, 1771) & 3 & & 2 & & \\
\hline 94 & Parthenos sylvia (Cramer, 1776) & 4 & & 2 & 2 & 1 \\
\hline 95 & Phaedyma columella (Cramer, 1780) & 3 & 1 & 2 & & \\
\hline 96 & Pseudergolis wedah (Kollar, 1844) & 2 & & & 2 & \\
\hline 97 & Stibochiona nicea (Gray, 1846) & 2 & 2 & 1 & 1 & \\
\hline 98 & Sumalia daraxa (Doubleday, 1848) & 3 & 1 & 2 & & \\
\hline 99 & Symbrenthia hypselis (Godart, 1824) & 3 & & 2 & 3 & \\
\hline 100 & Symbrenthia lilaea (Hewitson, 1864) & 3 & 5 & 12 & 3 & 4 \\
\hline 101 & Tanaecia julii (Lesson, 1837) & 3 & & 4 & 3 & 1 \\
\hline 102 & Tanaecia lepidea (Butler, 1868) & 3 & 1 & 3 & 2 & \\
\hline 103 & Vagrans egista (Cramer, 1780) & 4 & & 1 & 5 & 2 \\
\hline 104 & Vindula erota (Fabricius, 1793) & 3 & 2 & 5 & 3 & 3 \\
\hline \multicolumn{7}{|c|}{ Libytheidae } \\
\hline 105 & Libythea myrrha Godart, 1819 & 3 & & & 2 & 1 \\
\hline \multicolumn{7}{|c|}{ Riodinidae } \\
\hline 106 & Paralaxita dora (Fruhstorfer, 1904) & 1 & 1 & 1 & & \\
\hline
\end{tabular}


Table 1. Continue

Таблица 1. Продолжение

\begin{tabular}{|c|c|c|c|c|c|c|}
\hline 107 & Stiboges nymphidia (Butler, 1876) & 3 & 3 & 2 & & \\
\hline 108 & Zemeros flegyas (Cramer, 1843) & 3 & & 2 & 3 & 1 \\
\hline \multicolumn{7}{|c|}{ Lycaenidae } \\
\hline 109 & Acytolepis puspa (Horsfield, 1828) & 3 & 2 & 5 & 4 & \\
\hline 110 & Arhopala birmana (Moore, 1883) & 2 & 3 & 4 & & \\
\hline 111 & Arhopala elopura H.H. Druce, 1894 & 2 & 4 & 7 & & \\
\hline 112 & Caleta elna noliteia (Funhstorfer, 1918) & 3 & 2 & 2 & & \\
\hline 113 & Celastrina lavendularis (Moore, 1879) & 3 & & 5 & 2 & \\
\hline 114 & Curetis bulis Westwood, 1851 & 3 & & 1 & 1 & \\
\hline 115 & Heliophorus ila (de Niceville, 1896) & 2 & 5 & 8 & 1 & \\
\hline 116 & Jamipes bochus (Stoll, 1782) & 3 & 5 & 6 & & \\
\hline 117 & Jamides alecto (C.Felder, 1860) & 3 & 3 & 4 & & \\
\hline 118 & Lampides boeticus (Linnaeus, 1767) & 5 & & & 3 & 2 \\
\hline 119 & Nacaduba kurava (Moore, 1857) & 3 & & 5 & 4 & \\
\hline 120 & Prosotas nora (Waterhouse \& Lyell, 1914) & 3 & & 3 & 2 & \\
\hline 121 & Rapala rectivitta (Moore, 1879) & 2 & 1 & 2 & & \\
\hline 122 & Udara dilecta (Moore, 1879) & 3 & 2 & 5 & 2 & \\
\hline 123 & Yasoda androconifera Fruhstorfer, 1912 & 2 & 4 & 1 & & \\
\hline 124 & Zizeeria maha (Kollar, 1844) & 3 & & 3 & 12 & 4 \\
\hline \multicolumn{7}{|c|}{ Hesperiidae } \\
\hline 125 & Ancistroides nigrita (Latreille, 1824) & 3 & & 2 & 3 & \\
\hline 126 & Astictopterus jama C. Felder et R. Felder, 1860 & 3 & & & 2 & 3 \\
\hline 127 & Badamia exclamationis (Fabricius, 1775) & 4 & & 2 & 4 & 1 \\
\hline 128 & Bibasis vasutana (Moore. 1865) & 2 & & 4 & 2 & \\
\hline 129 & Capila pieridoides (Moore, 1878) & 2 & 1 & 1 & & \\
\hline 130 & Celaenorrhinus aurivittatus (Moore, 1879) & 2 & 4 & 3 & 1 & \\
\hline 131 & Celaenorrhinus putra (Moore, 1866) & 3 & 12 & 10 & 2 & \\
\hline 132 & Gerosis phisara Moore, 1884 & 1 & 1 & 2 & & \\
\hline 133 & Iton sp. & & & 1 & & \\
\hline 134 & Matapa aria (Moore, 1865) & 3 & 1 & 1 & & \\
\hline 135 & Notocrypta curvifascia (C. Felder et R. Felder, 1860) & 3 & 2 & 2 & 1 & \\
\hline 136 & Parnara bada (Moore, 1878) & 4 & & & 4 & 6 \\
\hline 137 & Pelopidas agna (Moore, 1865) & 4 & & & 4 & 5 \\
\hline 138 & Potanthus sp. & & 1 & 2 & 1 & \\
\hline 139 & Pseudocoladenia dan fabia (Evans, 1949) & 2 & 1 & 2 & & \\
\hline \multicolumn{3}{|c|}{ Total individuals } & 212 & 404 & 280 & 145 \\
\hline
\end{tabular}

NOTES. Order of species list of each family by Alphabet; DR — geographical distribution range; NF — natural forest; SF — secondary forest; $\mathrm{SH}$ - shrub and grass; $\mathrm{IH}$ - inhabitant.

ПРИМЕЧАНИЯ. В пределах каждого семейства виды перечислены в алфавитном порядке; DR - географическое распространение; NF — естественный лес; SF — вторичный лес; SH — кустарниково-травянистый биотоп; IH — антропогенный ландшафт. 
in CITES [New, Collins, 1991] is Troides aeacus (C. Felder et R. Felder, 1860). Some species are only recorded in the natural forest are Papilionidae - Troides aeacus, Atrophaneura varuna (White, 1868), Satyridae - Ethope noirei (Janet, 1896), and Amathusiidae - Stichophthalma fruhstorferi Röber, 1903. There are not any species merely recorded in one of other habitats.

Different habitats have different individual and species numbers of families. Table 2 shows the proportion of individual and species numbers of butterfly communities by families for different habitats. The families Amthusiidae and Satyridae have the most individual and species numbers in the natural forest: $56 \%$ individual number and $100 \%$ species number of the family Amathusiidae; $43.45 \%$ individual number and 92.85 species number of the family Satyridae. The family Riodinidae has the most species number in the secondary forest (100\% species).

Table 2. The proportion of individual and species numbers of butterfly communities by families in Xuan Son National Park.

Таблица 2. Доля особей и видов отдельно для каждого из семейств в сообществах дневных чешуекрылых Национального парка Хуан Сон.

\begin{tabular}{|l|r|r|r|r|r|r|r|r|}
\hline \multirow{2}{*}{ Family } & \multicolumn{4}{|c|}{ Individuals } & \multicolumn{4}{c|}{ Species } \\
\cline { 2 - 10 } & NF & \multicolumn{1}{|c|}{ SF } & \multicolumn{1}{c|}{ SH } & \multicolumn{1}{c|}{ IH } & \multicolumn{1}{c|}{ NF } & \multicolumn{1}{c|}{ SF } & \multicolumn{1}{c|}{ SH } & \multicolumn{1}{c|}{ IH } \\
\hline Amathusidae & 56.00 & 40.00 & 4.00 & 0 & 100.00 & 80.00 & 20.00 & 0 \\
\hline Danaidae & 18.18 & 50.00 & 25.00 & 6.82 & 72.73 & 90.91 & 72.73 & 27.27 \\
\hline Hesperiidae & 24.47 & 34.04 & 25.53 & 15.96 & 53.33 & 80.00 & 66.67 & 26.67 \\
\hline Lycaenidae & 24.03 & 47.29 & 24.03 & 4.65 & 62.50 & 93.75 & 56.25 & 12.5 \\
\hline Nymphalidae & 20.23 & 34.63 & 30.35 & 14.79 & 54.55 & 75.00 & 68.18 & 34.09 \\
\hline Papilionidae & 12.20 & 46.34 & 27.44 & 14.02 & 62.50 & 81.25 & 81.25 & 50.00 \\
\hline Pieridae & 4.71 & 31.76 & 37.65 & 25.88 & 40.00 & 86.67 & 100.00 & 60.00 \\
\hline Riodinidae & 30.77 & 38.46 & 23.08 & 7.69 & 66.67 & 100.00 & 33.33 & 33.33 \\
\hline Satyridae & 43.56 & 32.67 & 11.88 & 11.88 & 92.85 & 92.85 & 50.00 & 21.43 \\
\hline
\end{tabular}

NOTES. Habitats as the Table 1.

ПРИМЕЧАНИЯ. Местообитания как в Таблице 1.

Many families have the most individual numbers in the secondary forest such as the family Danaidae $(50 \%$ individuals), the family Hesperiidae (34.04\% individuals), the family Lycaenidae (47.29\% individuals), the family Nymphalidae (34.63\% individuals), the family Papilionidae (46.34\%), and the family Riodinidae (38.46\% individuals). The family has the most individual number in the shrub and grass habitat is Pieridae (37.65\% individuals).

As the pattern of individual numbers of families in the secondary forest, a majority of families has the most species number in the secondary forest such as Danaidae $(90.91 \%$ species $)$, Hesperiidae ( $80 \%$ species), Lycaenidae (93.75\% species), Nymphalidae (75\% species), and Papilionidae (81.25\% species).
The family has the most species in the shrub and grass is Pieridae (100\% species). There is not any family that has the most individual and species numbers in the inhabitant. There is not any species and individuals of the family Amathusiidae in the inhabitant.

The diversity of butterfly community in four different habitat types in Xuan Son National Park is presented in Table 3. The secondary forest has the greatest species and individual numbers (116 species, 404 individuals) and the inhabitant has the least (45 species, 145 individuals). The natural forest has fewer species and individual numbers ( 86 species, 212 individuals) than the shrub and grass habitat (94 species, 280 individuals).

Species richness index is highest in the secondary forest and lowest in the inhabitant. The evenness index

Table 3. Diversity of butterfly communities in four different habitat types in Xuan Son National Park. Таблица 3. Разнообразие сообществ дневных чешуекрылых в четырёх местообитаниях Национального парка Хуан Сон.

\begin{tabular}{|c|c|c|c|c|c}
\hline Habitat types & $\begin{array}{c}\text { Species number } \\
(\mathrm{S})\end{array}$ & $\begin{array}{c}\text { Individual } \\
\text { number }(\mathrm{N})\end{array}$ & $\begin{array}{c}\text { Species richness } \\
\text { index }(d)\end{array}$ & $\begin{array}{c}\text { Evenness } \\
\text { index }(J)\end{array}$ & $\begin{array}{c}\text { Diversity index } \\
\left(H^{\prime}\right)\end{array}$ \\
\hline NF & 86 & 212 & 15.87 & 0.92 & 4.15 \\
\hline SF & 116 & 404 & 19.16 & 0.95 & 4.53 \\
\hline SH & 94 & 280 & 16.50 & 0.94 & 4.30 \\
\hline IH & 45 & 145 & 8.84 & 0.91 & 3.49 \\
\hline
\end{tabular}

NOTES. Habitats as the Table 1.

ПРИМЕЧАНИЯ. Местообитания как в Таблице 1. 
is highest in the secondary forest where most families have the greatest individual numbers. The diversity index is highest in the secondary forest, lowest in the inhabitant. The greatest numbers of species, individuals, species richness index, and evenness index that lead the greatest diversity index of butterfly community in the secondary forest.

The similarity of species composition and abundance of butterfly communities between habitats is presented in Figure 1. The similarity of butterfly communities among habitats is divided into two groups. One group is between the secondary forest and the natural forest (66\%), and the other group is the shrub and grass and the inhabitant $(60 \%)$. The species composition of butterfly communities is rather similar between the secondary forest and the natural forest.

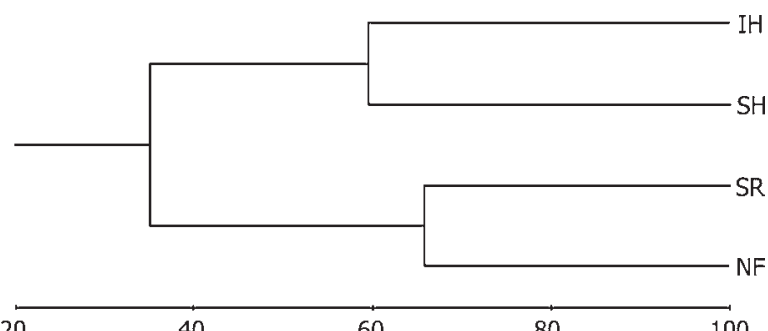

Fig. 1. The similarity of butterfly communities between habitats (habitats as the Table 1)

Рис. 1. Дендрограмма сходства сообществ дневных чешуекрылых различных местообитаний (местообитания как в Таблице 1).

The geographical distribution ranges of butterfly species from the smallest (R1) to the largest (R5) in different habitats with increasing forest clearance (from the natural forest to inhabitant are shown in Figure 2.

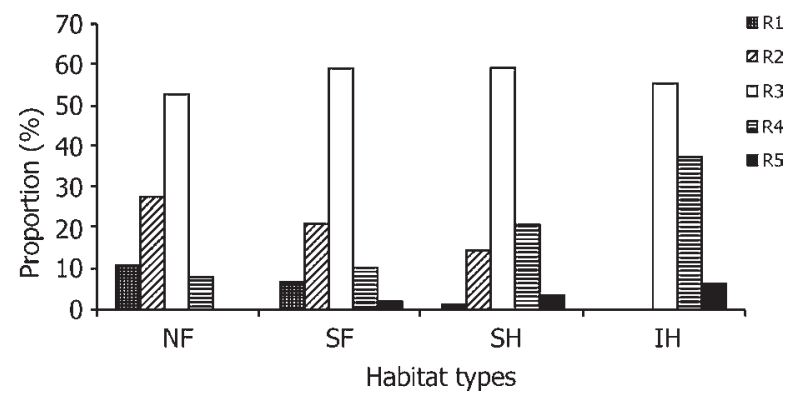

Fig. 2. Geographical distribution of species in different habitat types (habitats as the Table 1).

Рис. 2. Спектр зоогеографических групп дневных чешуекрылых в различных местообитаниях (местообитания как в Таблице 1).

Butterflies with the smallest range (R1) decreased in proportion to increasing forest habitat clearance. Species with the smallest range (R1) are absent from inhabitant. The share of species distributed in the Southeast Asian mainland (R2) also decreases gradually with increasing forest habitat clearance. The proportions of species with the most restricted (R1: Indochina) and larger geographical distribution range (R2: Southeast Asia mainland) decrease with increasing forest habitat disturbance: Indochina species $(r=-0.968 ; \mathrm{p}<0.05)$ and Southeast Asian mainland species ( $\mathrm{r}=-0.974$; $\mathrm{p}<$ $0.05)$. The share of species distributed in the IndoMalayan region is almost the same among habitats (from 53\% to 60\%). There was no significant difference in the proportion of species in the Indo-Malayan region $(\mathrm{r}=0.318 ; \mathrm{p}=0.740)$. As species ranges increased $(>$ Indo-Malayan region), the proportion grew with increasing forest habitat disturbance (e.g., species distributed in the Indo-Malayan and Australasian regions, and Palaearctic $(r=0.965 ; p<0.05)$; the Old World tropics, Holarctic, or Cosmopolitan $(r=0.978$; $<<0.05)$.

\section{Discussion}

The natural forest has fewer butterfly species and individuals than the secondary forest and shrub and grass. The inhabitant has the least species and individual numbers. This is similar to other studies showing that the disturbed/secondary forest has more butterfly species and individuals than shrub and grass habitats and agricultural lands [Vu, Yuan, 2003; Vu, 2009]. Living environment of disturbed/secondary forests is non homogeneous with a variety of vegetation in the intermediate procession. This consists of opening preferred growing plant species and shrubs. The disturbed/secondary forests have more diversity of plants of different processions than the natural forests and the stream sides. The more diversity of plants, the more diversity of insects [Price, 1975; Spitzer et al., 1987]. The secondary forest has more openings that provide more light and spaces to attract more butterfly species than the natural forest [Spitzer et al., 1997; Hill et al., 2001]. The disturbed/secondary forest also has more flowering plants which obviously support more butterfly species than the natural forest. Other studies also indicated that numbers of species and individuals of butterfly communities increase when natural forests disturbed; the diversity reaches the highest in moderately disturbed forests but decreases rapidly in urbanized forests [ $\mathrm{Vu}, 2009]$.

The natural forest has fewer species than the secondary forest and shrub and grass but all species of the family Amathusiidae and many species of the family Satyridae ( $92.85 \%$ species of the family) found in this habitat. The result of this study corresponds with previous work that shows the natural forest supports many species of the families Amathusiidae and Satyridae [Vu, 2007, 2009]. These families have many species with small geographical distribution ranges and mostly found in the forested habitats. Some species of these families are ecological indicators of forests [ $\mathrm{Vu}, 2007]$.

The shrub and grass has all species and many individual butterflies of the family Pieridae. Many species of this family prefer shrub and grass areas. The inhabitant in this study including agriculture land, is similar the agriculture habitat, has the lowest butterfly diversity. This result is similar previous works [ $\mathrm{Vu}, 2009,2013]$. Most of species found in this habitat are common and wide geographical distribution ranges. 
Species composition was dissimilar among habitats, but similar between forested habitats: the natural forest and secondary forest; and between shrub and grass and inhabitant. Most species fly in the natural forest, also fly in the secondary forest that makes the high similarity of species composition between these habitats. Many species flying in forested areas do not fly in the nonforested areas such as grass and inhabitant so the species composition of forested areas differs from species composition of the non-forested areas. Many species fly in the shrub and grass also found in the inhabitant areas so that the species composition of these habitat types is similar. The butterfly species composition differed among different habitat types and similar among similar habitat types, is similar with Steffan-Dewenter and Tscharntke [1997] and $\mathrm{Vu}$ [2009].

The proportion of species with the most restricted distributions is the highest in the natural forest, and decreases with increasing forest habitat clearance levels. The most characteristic species of natural forest show the smallest geographical ranges. They are forest species. The high proportion of endemic species in natural forest shows this natural forest habitat to be of high conservation value, although its species diversity is low compared to those in the secondary forest and the shrub and grass.

When forests are urbanized, the forest species tend to disappear due to the lost of their unique habitat [Brown, 1996; Blair, Launer, 1997]. They show low tolerance to forest destruction and a decreased ability to live in non-forested areas. Thomas [1991] also indicated that butterfly species with small geographical ranges have less ability to live in modified habitats than species with wider distributions. Lewis et al. [1998] emphasized that most of the widespread species follow humanimpacted habitats. The species found in inhabitant have the largest geographical ranges. They are open-land or non-forest opportunistic species.

The result of butterfly diversity pattern of limestone tropical forest is similar to the butterfly diversity pattern in other tropical forests [e.g. Spitzer et al., 1997; Vu, $2009,2013]$. The inhabitant habitat is similar the agricultural land where have very low butterfly diversity.

ACKNOWLEDGEMENTS. I would like to thank the Director and staff of Xuan Son National Park for permission to study butterflies in the park. Thanks to Luca Barrtolozzi and Italian colleagues for their support and collaboration between the Vietnam National Museum of Nature and the Natural History Museum of the University of Florence Italy.

\section{References}

Barlow H.S., Woiwod I.P. 1989. Moth diversity of a tropical forest in Peninsular Malaysia // J. Trop. Ecol. Vol.5. P.37-50.

Blair R.B., Launer A.E. 1997. Butterfly diversity and human land use: species assemblages along an urban gradient // Biological Conservation. Vol.80. P.113-125.

Bobo K.S., Waltert M., Fermon H., Njokagbor J., Muhlenberg M. 2006. From forest to farmland: butterfly diversity and habitat associations along a gradient of forest conversion in Southwest- ern Cameroon // Journal of Insect Conservation. Vol.10. P.2942 .

Brown K.S. 1996. The use of insects in the study, conservation and monitoring of biological diversity in Neotropical habitats, in relation to traditional land use systems // Decline and Conservation of Butterflies in Japan III, Proceedings International Symposium on Butterfly Conservation. The Lepidopterological Society of Japan. Osaka, Japan. P.128-149

Caldas A., Robbins R.K. 2003. Modified Pollard transects for assessing tropical butterfly abundance and diversity // Biological Conservation. Vol.110. P.211-219.

Chou L. 1994. Monographia Rhopalocerum Sinensium. Vol. 1-2. Henan: Henan Science and Technology Press. 851 pp. [in Chinese].

D'Abrera B. 1982-1985. Butterflies of the Oriental Region. Vol. 12. Melbourne: Hill House. 531 pp.

DeVries R.G. 1988. Outlines of entomology. $7^{\text {th }}$ edition. Hall: Chapman. 408 pp. (reprinted in 1992).

Fermon H., Waltert M., Vane-Wright R.I., Muhlenberg M. 2005. Forest use and vertical stratification in fruit-feeding butterflies of Sulawesi, Indonesia: impacts for conservation // Biodiversity and Conservation. Vol.14. P.333-350.

Hill J.K., Hamer K.C., Dawood M.M., Tangah J., Dawood D. 2001. Ecology of tropical butterflies in rainforest gaps // Oecologia. Vol.128. P.294-302.

Hill M.J., Monastyrskii A.L. 1999. Butterfly fauna of protected areas in North and Central Vietnam: collections 1994-1997 (Lepidoptera, Rhopalocera) // Atalanta. Vol.29. P.185-208.

Lekagul B., Askins K., Nabhitabhata J., Samruadkit A. 1977. Field guide to butterflies of Thailand. Bangkok: Association for the Conservation of Wildlife. $260 \mathrm{pp}$

Lewis O.T., Wilson R.J. \& Harper M.C. 1998. Endemic butterflies on Grande Comore: habitat preferences and conservation priorities // Biological Conservation. Vol.85. P.113-121.

Monastyrskii A.L., Devyatkin A.L. 2003. A system list of butterflies of Vietnam. Hanoi: Thong Nhat Publishing House. 56 pp. + 14 pls.

Morse D.R., Stork N.E., Lawton J.H. 1988. Species number, species richness and body length relationships of arboreal beetles in Bornean low land rain forest trees // Ecological Entomology. Vol.13. P.25-37.

New T.R., Collins N.M. 1991. Swallowtail Butterflies: An action plan for their conservation. Gland: IUCN. 36 pp.

Pollard E. 1977. A method for assessing changes in the Species richness of butterflies // Biological conservation. Vol.12. P.115134.

Posa M.R.C., Sodhi N.S. 2006. Effects of anthropogenic land use on forest birds and butterflies in Subic Bay, Philipines // Biological Conservation. Vol.129. P.256-270.

Price P.W. 1975. Insect Ecology. John Wiley. Sons Inc. 514 pp.

Primer-E Ltd. 2001. Primer 5 for Windows. Version 5.2.4.

Schulze C.H., Steffan-Dewenter I., Tsharntke T. 2004. Effect of land use on butterfly communities at the rainforest margin: a case study from Central Sulawesi // Land Use, Nature Conservation and the Stability of Rainforest Margins in Southeast Asia. Berlin - Heidelberg: Springer-Verlag. P.281-297.

Spitzer K., Jaroš J., Havelka J., Lepš J. 1997. Effect of small-scale disturbance on butterfly communities of an Indochina montane rainforest // Biological Conservation. Vol.80. P.9-15.

Spitzer K., Lepš J., Soldan T. 1987. Butterfly communities and habitat of seminatural savana in southern Vietnam (Papilionoidae, Lepidoptera) // Acta Entomol. Bohemoslov. Vol.84. P.200-208.

Spitzer K., Novotny V., Tonner M., Lepš J. 1993. Habitat preferences, distribution and seasonality of the butterflies (Lepidoptera, Papilionoidae) in a montane tropical rain forest // Vietnam. Journal of Biogeograph. Vol.20. P.109-121.

Steffen-Dewenter I. \& Tscharntke T. 1997. Early succession of butterfly and plant communities on set-aside fields // Oecologia. Vol.109. P.294-302.

Thomas C.D. 1991. Habitat use and geographic ranges of butterflies from the wet lowlands of Costa Rica // Biological Conservation. Vol.55. P.269-281. 
Vu V.L. 2007. Ecological indicator role of butterflies in Tam Dao National Park, Vietnam// Russian Entomological Journal. Vol.16. P.473-480.

Vu V.L. 2009. Diversity and similarity of butterfly communities in five different habitat types at Tam Dao National Park, Vietnam // Journal of Zoology. Vol.277. P.15-22.

$\mathrm{Vu}$ V.L. 2011. Diversity of butterflies in a tropical rain forest of Van Ban Nature Reserve, Lao Cai province, Vietnam // Russian Entomological Journal. Vol.20. P.411-418.

$\mathrm{Vu}$ V.L. 2013. The effect of habitat disturbance and altitudes on the diversity of butterflies (Lepidoptera, Rhopalocera) in a tropical forest of Vietnam: results of a long-term and large-scale study // Russian Entomological Journal. Vol.22. P.51-65.
Vu V.L., Vu Q.C. 2011. Diversity pattern of butterfly communities (Lepidoptera, Papilionoidae) in different habitat types in a tropical rain forest of southern Vietnam // ISRN Zoology. Article ID 818545.8 pages. http://dx.doi.org/10.5402/2011/ 818545.

Vu V.L., Yuan D.C. 2003. The differences of butterfly (Lepidoptera, Papilionoidea) communities in habitats with various degrees of disturbance and altitudes in tropical forests of Vietnam // Biodiversity and Conservation. Vol.12. P.10991111.

Warren M.S. 1985. The influence of shade on butterfly numbers in woodland rides, with special reference to the Wood White Leptidea sinapis // Biological conservation. Vol.33. P.147-164. 